\title{
SMITHSONIAN INSTITU'TION.
}

UNITED STATES NATIONAL MUSEUM.

\section{NOTES ON TRIASSIC PLANTS FROM NEW MEXICO.}

W. M. FONTAINE AND F. H. KNOWLTON.

From the Proceedings of the United States National Museum, V'ol. XIII, pages $281-285$, and Plates XXII-XXVI.

$$
\text { [No. 82I.] }
$$

WASHINGTON:

GOVERNMENT IRINTING OFFICE.

1890. 

NOTES ON TRIASSIC PLANTS FROM NEW MEXICO.

WM. M. Fontaine and F. H. KNowlton.

(With P'lates xxif-xxir)

In 1886 a small collection of fossil plants was made by Maj. .J. WV. Powell at the Copper Mines near Abiquin, New Mexico, and dnring lhe past season (1889) the sa!ne locality was visited by I’rof. F. H. Knowl ton who obtained additionial material. The plant impressions were referred to me by Prof. Lester F. Ward for determination, and sections of the wood obtained have been nade and studied by P'rofessor Knowiton.

DESCRIP'TION OF THF LOCALI'TY.

13y F. II. KNowLtos.

The little village of Abiquin stands upon a bluff overlooking the valley of the Chama River, and is about $2 \mathrm{i}$ miles northwest of FispaInola, the terminal point of the branch of the Denver and Rio Grande liailroad, and about 50) miles northwest of Santa Fí, New Mexieo. The general topographic and geologic features of the surrounding country have been so thoroughly describerl by Dr..J. S. Newberry, who was attached as geologist to the "Ixploring Experition from Santa Fé, New Mexico, to the . Inuction of the Granl and (rreen Rivers" under Capt. I. N. Macomb, in 1859, that little remains to be adderl.

The copper mines which have been known and worked by the Mexicaus for a very loug time, are aloont 6 miles nortleast of Abiquiu and about 1,000 feet above the valley of the Chama. After leaving the (Hana, which on the nortl sicle at this point is characterized by a little lateral valley eroded from mostly whitish coarse sanclstone probably of Tertiary age, we enter anotler valles, or rather almost a cañon, which has been eut through 'Triassic rocks. 'The sicles of this cañon exlibit bauds of rarionsly colored sandstones, the colors being red, white, yellow or orange, and the strata being nearly lorizontal.

At the top of the mountain a large oroled basin is entered from the southeast. This basiu, which according to Newberry drains into the Cliana Valley, is about $1 \frac{1}{2}$ miles from south to north and 1 mile from east to west, and is surrounded by a wall, in some places nearly verti. cal, between 500 ant 600 feet high. This wall is composed at base of sandstones and narls about 200 feet in thickness, above which is a 
stratmm of redolish finc framel samblstones, also abont 200 foet in thickness, the whole being eapperl by a layer of coarse-gramed, yel. lowisl sandstones 150 feet or more in thiekness.

In some places the second of the above mentioned strata has the sandstone of a yellowish or nearly white color, and it is in this material on the eastern side that tho olil copper mines are locaterl. There are but three openings visible at the present time. The openings are 5 or 6 feet square and descend at a slight angle, the deepest being only abont 75 feet. Only one is braneherl, and none of them are bracerl nu) with timbers at the present time. At the time the mines were visited by Dr. Newber'y they were braced up with heary timbers, and there was evidence of quite an extensive series of tmmols. It is possible that the mines visited are not the same as those mentioned by Dr. Newberry, as they have boen reently worked, and exlibit none of the evidenees of great antiquity noticed by him, but these were the only mines known to the gruide, who was a native of Abiquiu, and had worked in the mines. The copper oecurs as a smplinle of eopper and iron, and as iron earbonate, and is distributed thusugh a layer hardly more than 4 feet in thickness. It las replated the trunks of trees and varions vegetable stems and fragments, and also ocenrs in eoneretions about and among the quart\% pebbles.

Just abovo the openings of the mines ocenrs a layer of earbonaceons shale, abont $S$ inches in thickness, which (entains fossil plants. The material splits very realily into thin lamina and is very fragile. The surface of the shale is covered witl such a mass of vegetable inpores. sions that it is with eonsiderable diffenlty that anything ean be mate ont; but by removing a consislerable quantity of the material a fairly clear ulisplay of the plants was obtained.

From the same white sandstone, about 10 feet above the shale holil. ing the plant impressions, considelable fossil woorl was obtainerl. One trunk, which was 2 feet 8 inches in liameter, was observed in place in the sandstone, and numerons pieces of greater or less size were seattered abont. While only one trunk was aetuaily found in situ there is every evirlence to indicate that the loose pieces came fiom the immethate vieinity. The wool is fairly well preserved and, as the mieroseopical examination slowed, retains the strneture in a manner which allowsits satisfactory stmdy aud determination.

The new (eopper mines, which were opened during the spring of 1589, are in the northwestern part of the basin. 'They are locaterl in a white very conrse.grained saudstone which, as there exposerl, forms the floor of the hasin and is eonsequently several humber feet lower than the olil mines. 'The eopper oceurs, in the form of woor or stems only. Some of the stems hear evilence of laving heen large but ane now musilerably disintegraterl. The strueture las almost entirry disappearen form tinses stems, bnt a curefilly selected section shows traces of it to be still retained. 
Associated with these stems are tho casts of many large and small stems of Equisetum; but the matrix is by fur too coarse and granular to successfully preserve delicate leares or fronds.

DESCRIPTION OF TIIE SPECIES.

By WM. M. Fontaise.

\section{1.-Plants of the lower horizon or from the new eopper mines.}

Equisetum Abiquiense sp. nov. lontaine. Plate xxir, fig. 1.

This is preserved in a coarse white sandstone. It is characterized by the considerable width of the ribs, their flatness, and the great number and distinctness of the scars left by the articulation of the leaves. Tho larger piece innst have formed a part of a stem 6 inches in dianeter.

This fossil, forming cast No. 1 , is much like Sehizoneura planieostatu, Rogers spec., the Calamites planieostatus of the Richmond coal field, and may be the same plant. As, however, no impressions of Schizonenra have been found in this formation, and as the other fossil found with it is certainly an Equisetum, it seems best to regard this as an Equisetum also until portions more decisive of character are fonnd. For convenience of reference it may be called Equisetum Abiquiense. Two specimens, internal casts.

Equisetum Knowltoni sp. nov. Fontaine. Plate xxın, Figs. 2-4.

This cast is preserved in a fine grained white sandstone. The casts on their exterior are usually impregnated with malachite, the carbonaceous matter seeming to have been active in precipitating the copper from solution. These impressions evidently were formed by a plant very different from that yielding cast No. 1.

These casts are characterized by the possessiou of numerous very short internodes, very narrow prominent ribs, and by the entire absence of the scars of leaf-articulations. The shortest internodes are 1 centimeter in length, one specimen (Fig. 4) showing six of these. The longe t are 22 millimeters in length. The widest ribs are 1 millimeter in breadth and the narrowest about one-third of a millimeter, and the average is about one-half of the same. In the narrowness of the ribs this plant resembles the internal casts of Equisetum Rogersi of the Richmond Coal Field, the impressions that were called Calumites arenueeus. The persistent shortness of the internodes, however, is a feature which distinguishes this from the Virginia plant. It might be ealled Equisetum Knoultoni. Six specimens; interual casts.

\section{II.-Plants of the upper horizon or from the old copper mines.}

As Mr. Knowlton yoints out, the plants of this higher horizon are totally different from those lower down. I find anong them none of the impressions of Equiseta that form all of the fossils of the lower lorizon. 
It must, howerer, be borme in mind that this difference may in part be dne to the aceidents of preservation, as the coirse samdstone of the new mine could not preserve imprints of leaves. No previons collector seems to have found fossils at the lower horizon. Dr. Newberry gives no imprints of Equiseta from the Abiquin Copper Mines, and the material collected by Major Powell in 1886, which I lave examined, evidently comes from the higher horizon. The shate, however, which carries the impressions collected by llajor Powell is moro siliceons and indurated than that obtained by Mr. Knowlton, which may be dine to the firet that it was got from a different place in the stratnm. The follow. ing are the plants identified from this loeality :

1. Zamites Powelli sp. nov. l'outaine.

2. Cheirolepis Munsteri Schimp.

3. Zamites oreidentulis? Nowb.

4. I'alissya Braunii? Endl.

5. P'alissya cone? (specimen 13).

(i. Cycarlites? (specimen 23).

7. Ctenophyllum?

Zumites Powelli (Figs. 5-7) oceurs as a great rarity among the specimens collected by Major Powell, but is the most common of the imprints found by Mr. Knowlton. It is nearest to Zamites Feneonis Brongu., among previous described plants, but does not seem to be identical with it and is probably new. It does not seem to have been found in the plants deseribed by Newberry from Los Bronces and the copper mines near Abiquin. It has wider and longer leaflets than \%.occidentulis Newb., and they are more bluntly terminated than those of $Z$. Feneonis Brongn.

Cheirolepis Munsteri Schimp. is proportionally much less common anong these plants than those collected by Major Powell, and the imprints are imperfectly preserver.

One specimen of Zamites oecidentalis? Newb. was seen and it was too obseure to permit of a positive identilication.

Palissya Braunii ? Endl, ocenrs in several specimens. It is certainly a Palissya and seems to be very near l'ulissyu biannii, bnt the specimens are not well enough preserved and large (nongh to permit of a positive identifieation. It seems to be the same with the plant figured as Palis. sya? in Newberry's Geological Report of the Macoml, lixperlition, Plate VI, Fig. 10.

I'ulissya cone? This fossil, seen in only one specimen, is most probably the cone of a Palissya, and probably belongs to the speeies which has been donbtfinlly identified with I'. Brannii busll. This cone is mueh like that given by Newberry in his Report on the (ieology of the Mateomb) lixpedition, l'late V, Fig. 5. It is shorter and has longer seales than the one given by Schenk as the cone of P. Braunii. (See Foss. Flora der Grenzschichten, tafel xur, Fig. 7.)

Speeimen 13 is an obsenre imprint, which seems to be a Cyendites. This is indieated by the narrow, stiff leaves, namowerl at base to a peduncle and by what seems to be a midrib in the leaves. It is not well enongh preserved to be identiffed with certainty. 
Several specimens show long, strap-shaperl leaflets, which never possess either base or termination. They look much like Ctenophyllum grandifolium of the older Mesozoicor Riclmond Coal Field of Virginia, but are not well enongh preserved to be ecrtainly made out. They may be fragments of Newberry's Pterophyllum robustum, found at Los Bronces, and this is apparently the same as Ctenophyllum grandifolium.

These fossils from the copper mines near Abiquiu are not numerous enougl and suficiently well preserved to enable one to determine with positiveness the age of the strata which contain them. They, however, indicate that the beds are not older than the Rhetic.

\section{FOSSIL WOOD FIOM TIIE OLD COPPER MINLS.}

\section{By F. H. KNOwLToN.}

Araucarioxylon Arizonicum Knowlton $*$ is represented by seren pieces of wood which, as stated above, were obtained from sandstone about 10 feet above the shale containing fossil plants at the old eepper mines. The material is not as perfectly preserved as that from which the species was described, but it is snfliciently clear to indicate that it is identical with it.

In transverse section the annual rings are found to consist of only three or four layers of tangentially compressed cells as in the type. The remaining cells are of nearly uniform size alid possess thick walls.

The radial section is very obscure, and in only one or two limited areas is it possible to demonstrate the presence and outline of the punctations. They are arranged in a single longitudinal row in the center of the cell. No double row of punctations conld be detected, but this condition was not of frequent occurence in the type specimens. The medullary rays consist of relatively short cells as in the type.

In tangential section the medullary rays are observed to be in a single series of superposed celk, and range from one to twenty or more in number. The punctations that were described in the type specinens conld not be detected in this material, and, indeed, a further examination of material from the type locality shows that these tangential punctatious are not all uniformly present.

Coniferous Irood? As before stated the deposits of copper occur as displacements of regetable stems, from which, in most cases, the structure has entirely disappeared. Sections were mate from exceptionally well preserved specimens from the new eopper mines, and these show the outlines of a few cells which are arranged in radial rows and separated by what must be medullary rays, although these latter are only imperfectly preserved. This seems to indieate that it was a solid stem, and from the general appearance it most probably represents a coniferous woorl.

* Knowlton in P'roc, V. S, Nat. Mus., vol. xI, 18-5, Pl. 1-4, Pl. 1. 



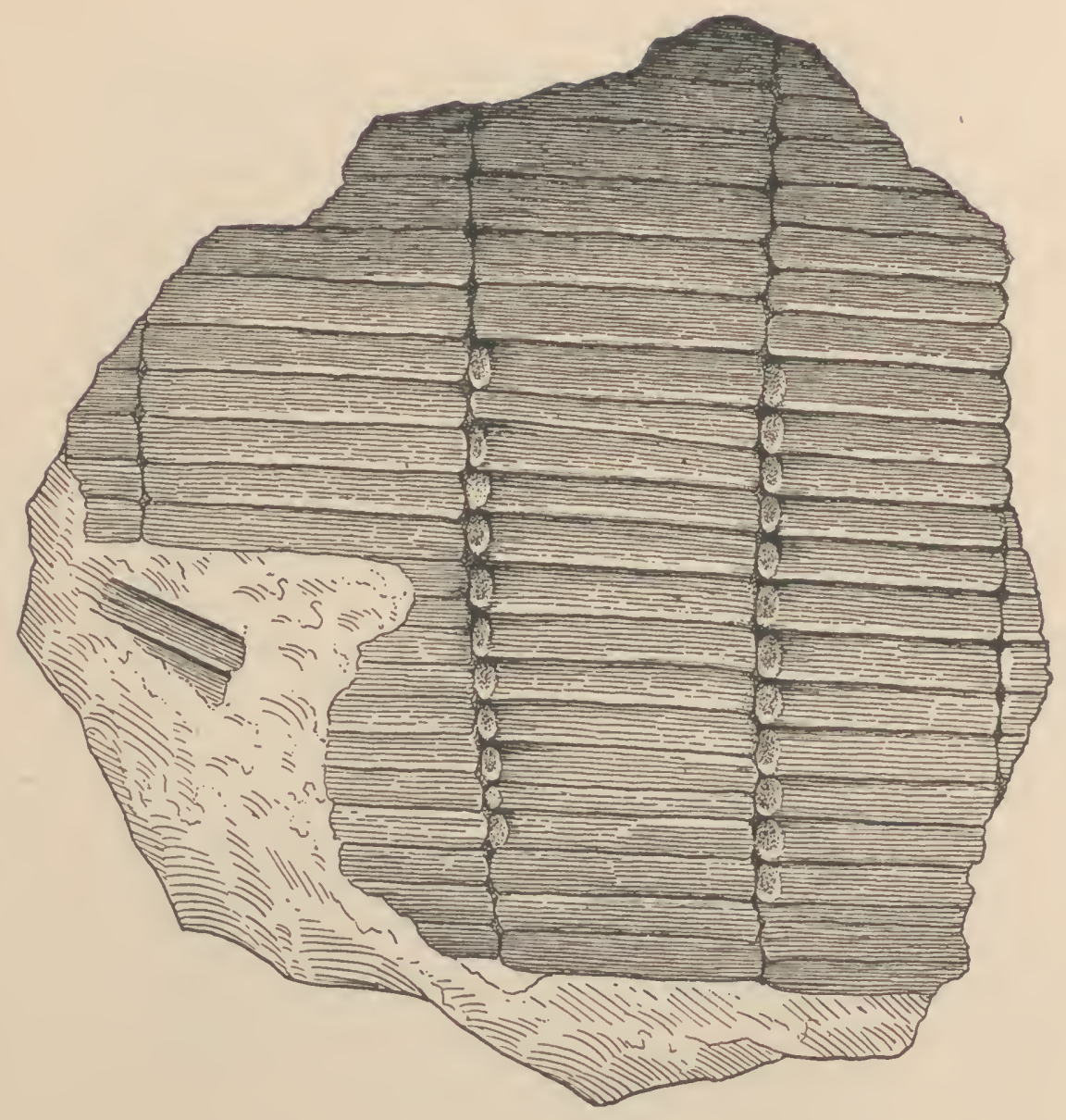

FIG. 1. EQUISETUM ABIQUIENSE, new species. 



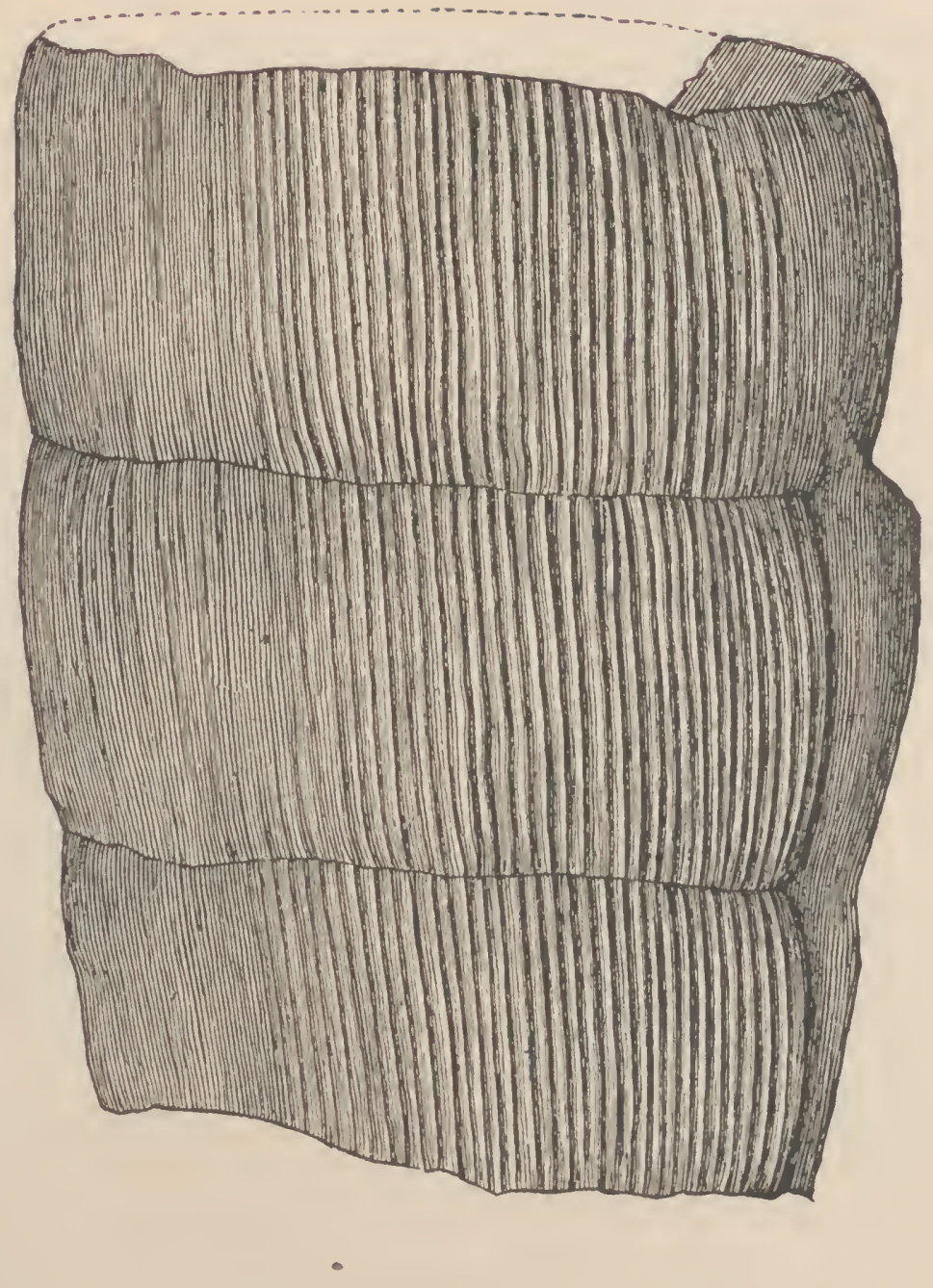




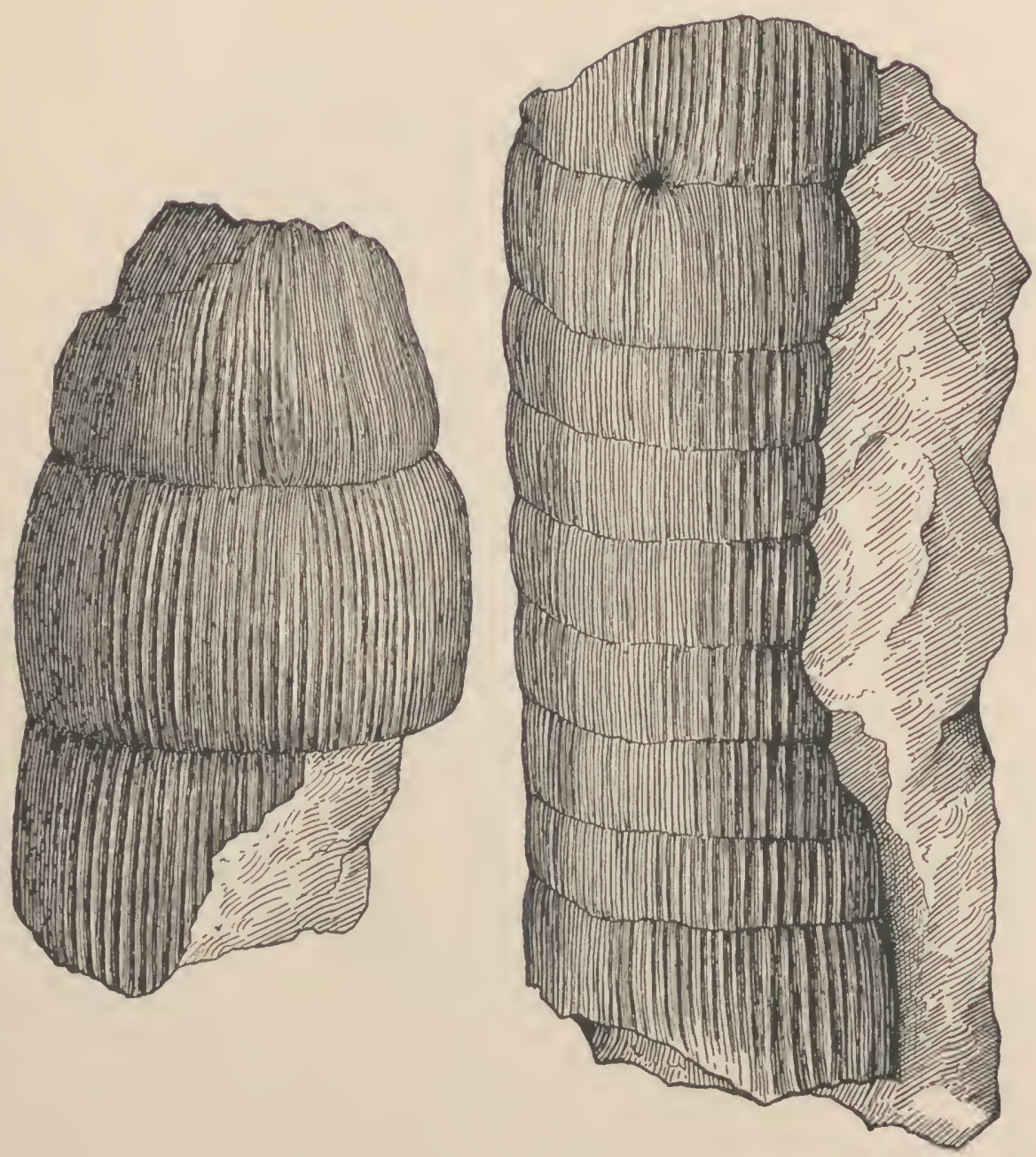



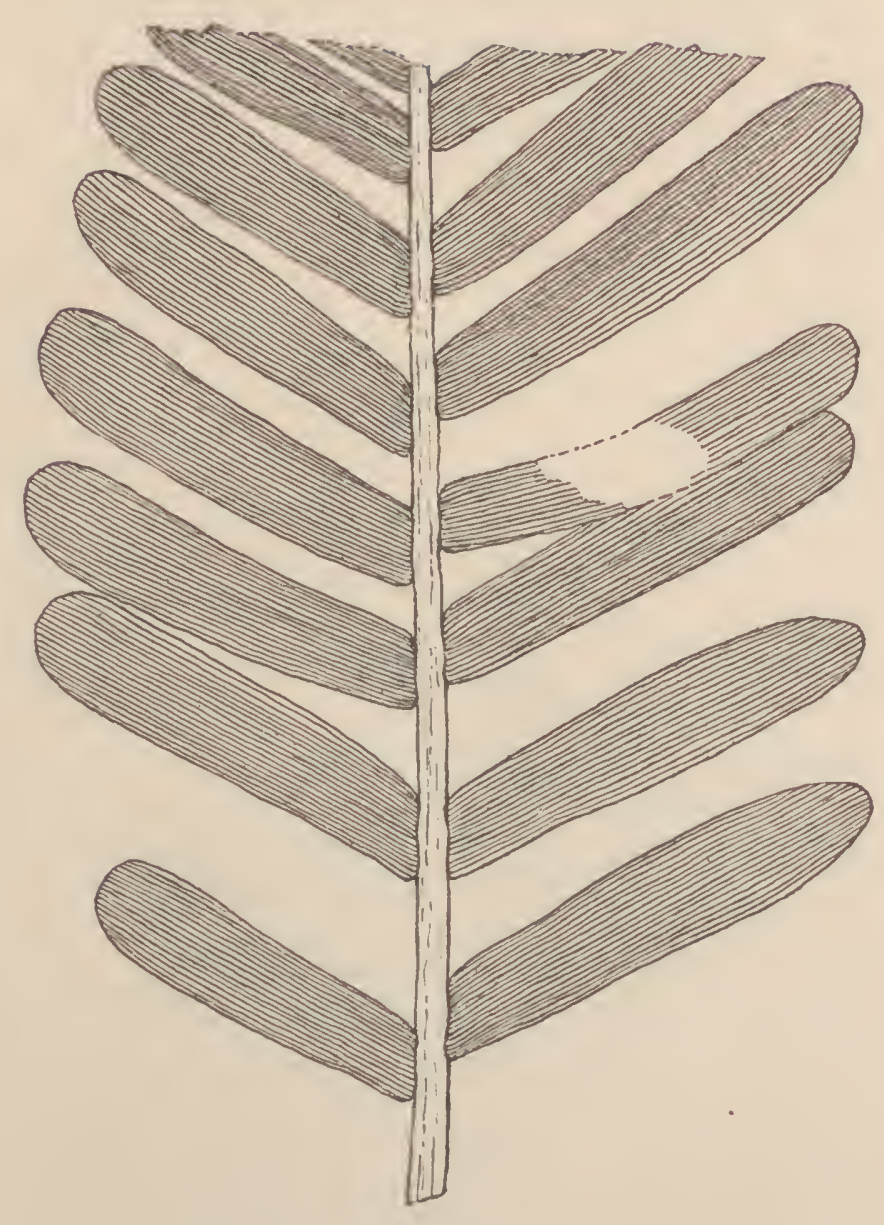

FIG. 5. ZAMITES POWELLI. new species. 


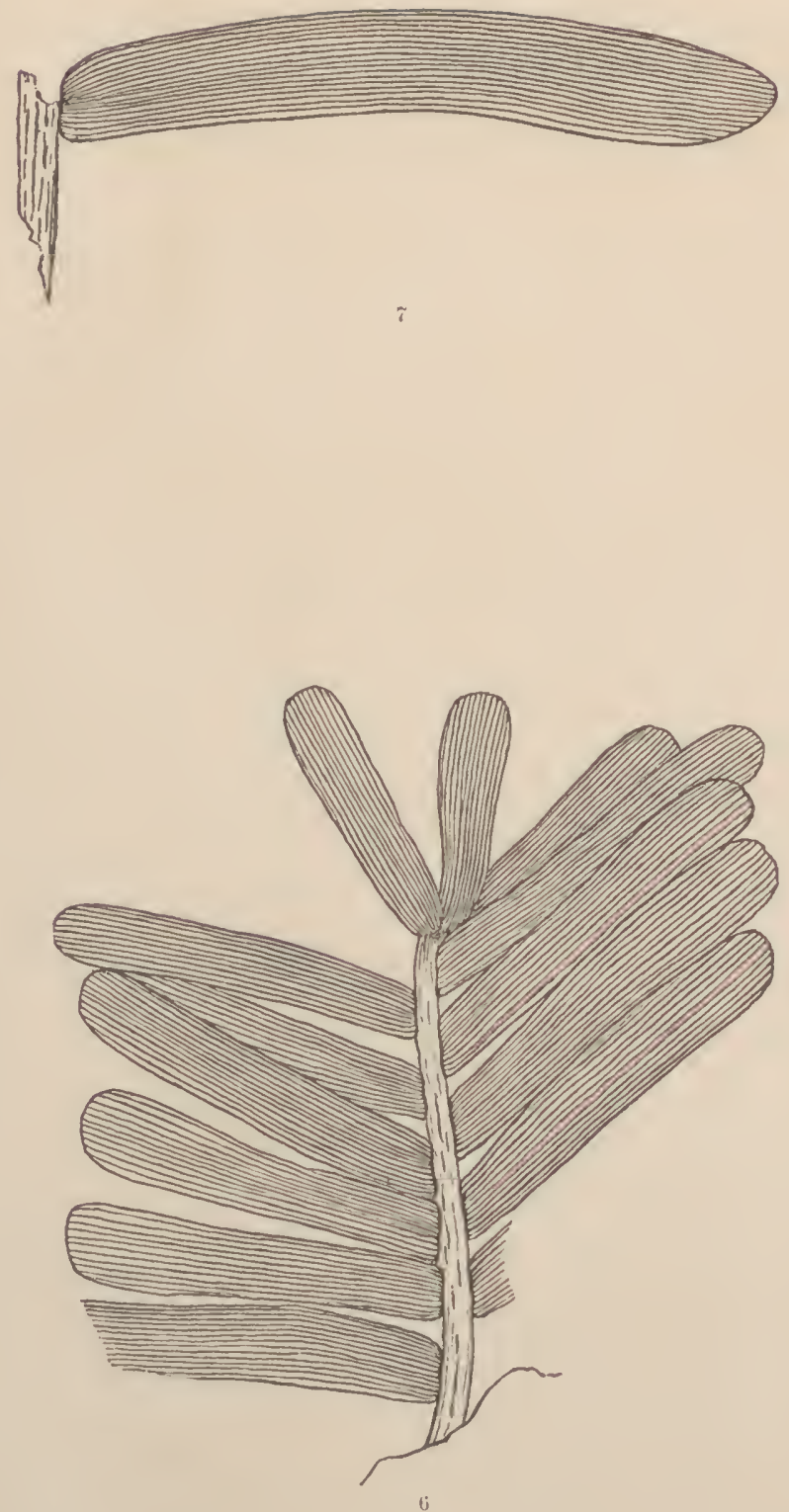

Figs, 6, 7. ZAMITES POWELLI, new species. 
